\title{
BIOBASED NANOEMULSION FOR BLOCKING COVID-19 FROM ACCELERATING ALZHEIMER'S DISEASE
}

\author{
J. S. D'Arrigo (1D \\ Cavitation-Control Technology Inc. \\ Farmington, CT 06032, USA \\ $\bowtie D^{\prime}$ Arrigo Joseph - cavcon@ntplx.net
}

An effective therapeutic strategy to delay dementia could be based upon nanotargeting drug(s), using lipid nanocarriers (i.e., biobased nanoemulsion technology), toward a major serum amyloid A (SAA) receptor responsible for certain proinflammatory, SAA-mediated, cell signaling events. For example, other investigators have already confirmed that SR-BI receptors (or its human ortholog CLA-1) function as proinflammatory cell-surface SAA receptors, and additionally report that various ligands for CLA-1/SR-BI "efficiently compete" with SAA for CLA-1/SR-BI binding. A similar benefit (of "competitive binding") may well accompany the clinical intravenous use of the ("HDL-like") lipid nanocarriers (i.e., biobased nanoemulsion [see above]), which have already been repeatedly described in the peer-reviewed literature as a targeted (and SR-BI mediated) drug-delivery agent. To conclude, the above-proposed "competitive binding", between SAA and such biobased nanoemulsion(s), could assist/enhance the protective (ordinarily anti-inflammatory) role of $\mathrm{HDL}$ - as well as provide targeted drug-delivery to the (human) brain cells bearing CLA-1/SR-BI receptors. The first resulting advantage is that this (intravenous) colloidal-nanocarrier therapeutic makes it possible for various cell types, all potentially implicated in Alzheimer's disease and/or (late-onset) dementia, to be simultaneously sought out and better reached for localized drug treatment of brain tissue in vivo. A second major advantage is that this therapeutic-target approach has particular relevance to the current COVID-19 human pandemic; namely, immune response and excessive inflammation in COVID-19 infection may accelerate the progression of brain inflammatory neurodegeneration which, if effectively halted, might play a major role in reducing Alzheimer's disease pathology.

Keywords: Alzheimer's disease, dementia, drug nanotargeting, inflammation, nanocarrier, nanoemulsion.

Conflict of interest: The author declares the following potential conflicts of interest:

1. Joseph S. D'Arrigo is employed at Cav-Con Inc.

2. The actual "LCM/ND nanoemulsion (nanoparticle)" described in this review is not a finished/ manufactured product, and is not on the retail market for sale.

For citation: D'Arrigo JS. Biobased Nanoemulsion for Blocking COVID-19 from Accelerating Alzheimer's Disease. Juvenis scientia. 2021;7(4):5-11. DOI: 10.32415/jscientia_2021_7_4_5-11. 


\title{
НАНОЭМУЛЬСИЯ БИОЛОГИЧЕСКОГО ПРОИСХОЖДЕНИЯ ДЛЯ ПРЕДОТВРАЩЕНИЯ СТИМУЛИРУЮЩЕГО ВЛИЯНИЯ COVID-19 НА РАЗВИТИЕ БОЛЕЗНИ АЛЬЦГЕЙМЕРА
}

\author{
Дж. С. Д’Арриго \\ Cavitation-Control Technology Inc. \\ США, Коннектикут, 06032 г. Фармингтон \\ $凶$ Д’Арриго Джозеф С. - cavcon@ntplx.net
}

Эффективная стратегия лечения, направленного на замедление прогрессирования деменции, может быть основана на применении таргетных нанопрепаратов, созданных с использованием липидных нанопереносчиков (технологии получения наноэмульсий биологического происхождения). Эти нанопереносчики должны доставлять препарат к основному рецептору сывороточного амилоида A (SAA), который обеспечивает активацию определенных провоспалительных сигнальных путей внутри клеток. В ряде исследований было показано, что рецепторы SR-BI (или их человеческий ортолог CLA-1) действуют так же, как и провоспалительные рецепторы SAA, расположенные на поверхности клеток. Помимо этого, в литературе дополнительно сообщается, что различные лиганды CLA-1/SR-BI «эффективно конкурируют» с SAA за связывание с CLA-1/SR-BI. Подобное преимущество («конкурентного связывания») может также наблюдаться при внутривенном введении в клинических условиях липидных (ЛПВП-подобных) нанопереносчиков (вышеупомянутой наноэмульсии биологического происхождения), которые были неоднократно описаны в рецензируемых изданиях как один из способов таргетной (в том числе SR-BI-опосредованной) доставки лекарственных препаратов. В итоге такое «конкурентное связывание» SAA с соответствующими наноэмульсиями может поддерживать/усиливать защитную (как правило, противовоспалительную) функцию лПВП, а также обеспечивать адресную доставку лекарственных средств в клетки головного мозга (в том числе и человека), несущие рецепторы SR-BI (в случае человека - CLA-1). Первым преимуществом этого подхода является то, что при внутривенном введении препарата с нанопереносчиком можно оказывать эффекты на потенциально вовлеченные в развитие болезни Альцгеймера и/или сенильной деменции клетки различных типов, обеспечивая прицельное воздействие на ткань головного мозга in vivo. Второе важное преимущество заключается в том, что этот таргетный терапевтический подход имеет особое значение в контексте текущей пандемии COVID-19, так как именно иммунный ответ и избыточная воспалительная реакция при COVID-19 могут ускорить прогрессирование процесса воспалительной нейродегенерации в головном мозге. Эффективное блокирование данного процесса может значительным образом ограничить развитие патологических изменений, характерных для болезни Альцгеймера.

Ключевые слова: болезнь Альцгеймера, деменция, таргетный нанопрепарат, воспаление, нанопереносчик, наноэмульсия. 
Конфликт интересов: Автор заявляет о следующем потенциальном конфликте интересов:

1. Дж. С. Д’Арриго является сотрудником Cav-Con. Inc.

2. Описанная в настоящем обзоре наноэмульсия (наночастица) LCM/ND не является готовым/производимым продуктом и не доступна для приобретения на розничном рынке.

Для цитирования: Д’Арриго Дж.С. Наноэмульсия биологического происхождения для предотвращения стимулирующего влияния COVID-19 на развитие болезни Альщгеймера // Juvenis scientia. 2021. Tom 7. № 4. C. 5-11. DOI: 10.32415/jscientia_2021_7_4_5-11.

1. Introduction: Recent research (e.g., $[1,2]$ ) indicates that chronic inflammatory stimulus in the gut may induce (e.g., via serum amyloid A (SAA)) the release of proinflammatory cytokines. At the same time, increased blood-brain barrier (BBB) permeability due to aging (or dysfunction), in turn, allows these proinflammatory cytokines to enter the brain, inducing glia reactivity $[1,2]$. These recent findings, and various past studies, indicate that inflammation plays an important role in the process of amyloid- $\beta$ $(A \beta)$ deposition and, therefore, the inhibition of inflammatory cascades may attenuate amyloidogenic processes - such as Alzheimer's disease [3] (cf. [4]). Hence, an effective preventive and therapeutic strategy could be based upon nanotargeting $\operatorname{drug}(\mathrm{s})$ toward a major SAA receptor responsible for numerous SAAmediated cell signaling events leading to cognitive decline and eventually Alzheimer's disease or (late-onset) dementia $[5,6]$.

2. Serum Amyloid A (SAA) versus SR-BI Targeting, and Cognitive Impairment. Earlier research [5-9] has already confirmed that SR-BI receptors (or its human ortholog CLA-1) function as cell-surface SAA receptors - which bind, internalize, and mediate SAA-induced proinflammatory effects (cf. [8]). However, Baranova et al. additionally report that (in cell culture) ligands for CLA-1/SR-BI "efficiently compete" with SAA for CLA-1/SR-BI binding [7]. (For example, it has already been documented in the literature that both apoA-1 and SAA are substrates for SR-BI, which indicates that SR-BI could mediate the transport of both proteins across the blood-brain barrier (e.g., [9]).) Not surprisingly, therefore, Robert et al. have recently asserted that many lines of evidence suggest a protective role for high-density lipoprotein ( $\mathrm{HDL}$ ), as well as this lipoprotein particle's major apolipoprotein (apo)A-1, in Alzheimer's disease [10]. Accordingly, a similar benefit (of "competitive binding" to SR-BI receptors) may well accompany the clinical intravenous use of the ("HDL-like") LCM/ND lipid nanoemulsion vehicle (cf. [5]) which has already been repeatedly described in the peer-reviewed literature (based upon numerous in vivo animal studies) as a targeted, apoA-1-based, (SR-BI mediated) drug-delivery agent (e.g., [5, 11]). Moreover, by incorporating drug molecules into the LCM/ND lipid nanoemulsion type, one is likely to obtain a multitasking "combination therapeutic" capable of targeting cell-surface SR-BI. This (intravenous) colloidal-nanocarrier therapeutic would make it possible for various cell types, all potentially implicated in Alzheimer's disease [12, 13] and/ or (late-onset) dementia, to be simultaneously sought out and better reached for localized drug treatment of brain tissue in vivo [5, 11, 14-16].

\section{COVID-19, \\ ("HDL-like") \\ LCM/ND Nanoemulsion, and (late-onset) Dementia.} From the descriptions provided in Sections 1 \& 2 above, it is already apparent that SAA accumulation in HDL reduces this lipoprotein's "antiinflammatory capacity" - due to the accumulated SAA activating proinflammatory signaling pathways. Since it plays a key role in decreasing HDL functionality, SAA represents an interesting therapeutic target for influencing the fate of cardiovascular-related disease [17]. Finally, as concerns this concept of an HDL-related therapeutic target, the above Sections also explained why anticipated "competitive binding" between 
SAA and (HDL-like) LCM/ND nanoemulsion particles, occurring at above-described "(human) CLA-1/(rodent)SR-BI receptors" (cf. Sect. 2), may well accompany clinical intravenous use of such nanoemulsion (which is repeatedly described in the literature as a targeted, apoA-1-based, (SR-BI mediated) drug-delivery agent $[5,11])$ (cf. [18]).

Meanwhile, much evidence indicates a protective (i.e., ordinarily anti-inflammatory) role for $\mathrm{HDL}$, and its major apolipoprotein (apoA1), in Alzheimer's disease (e.g., [5, 11, 18-20]) (cf. [21]). Hence, the above-proposed "competitive binding", between SAA and the LCM/ ND nanoemulsion, could assist/enhance the "protective (ordinarily anti-inflammatory) role" of $\mathrm{HDL}$ - as well as provide targeted drugdelivery to the (human) brain cells bearing (CLA$1 /$ SR-BI receptors. This novel therapeutic-target approach has particular relevance to the current COVID-19 human pandemic. Namely, immune response and excessive inflammation in COVID-19 infection may accelerate the progression of brain inflammatory neurodegeneration, which plays a major role in Alzheimer's disease pathology. In addition, individuals with type 2 diabetes are at increased risk for Alzheimer's disease, as well as for severe outcomes after COVID-19 infection [22]. Severely affected COVID-19 cases experience high levels of proinflammatory cytokines and acute respiratory dysfunction. All these COVID-19-related homeostatic disruptions have the potential to cause cognitive decline (resulting from direct negative effects of the immune reaction, acceleration or aggravation of pre-existing cognitive deficits, and/or de novo induction of a neurodegenerative disease). Accordingly, patients surviving COVID-19 are at risk for subsequent development of neurological disease and in particular Alzheimer's disease [23].

4. Concluding Remarks: Recent reviews (e.g., [5, 24-26]) of human Alzheimer's-disease studies have noted a significant elevation in inflammatory mediators in the cerebral microcirculation; crucially, inflammation has a key role in linking several types of vascular and neuronal damage (in Alzheimer's-disease brain) with cardiovascular risk factors, such as arterial stiffness and hypertension [24]. In addition, various past studies (cf. [5]) indicate that inflammation also plays an important role in the actual process of $A \beta$ deposition and, therefore, the inhibition of inflammatory cascades may attenuate amyloidogenic processes - such as Alzheimer's disease. Hence, an effective preventive and therapeutic strategy could be based upon nanotargeting $\operatorname{drug}(\mathrm{s})$, using lipid nanocarriers, toward a major SAA receptor responsible for numerous SAA-mediated cell signaling events leading to cognitive decline and eventually Alzheimer's disease or (late-onset) dementia. Lastly, it has been reconfirmed in the current literature that receptor-mediated endocytosis/transcytosis via lipoprotein receptors, particularly scavenger receptors including SR-BI, remains a major route of drug delivery across the blood-brain barrier; namely, recently published work has demonstrated that (blood-borne) nanocomplexes can be readily transported into brain capillary endothelial cells (bovine and porcine) via SR-BI receptor-mediated endocytosis [27] (see also [28-30]). Accordingly, the effects of the various cell types targeted (via SR-BI) may be additive, multiplicative, or otherwise synergistic. Moreover, recent research (e.g., [5, 31-34]) repeatedly indicates for several age-related diseases, including cardiovascular and neurodegenerative disease, that accompanying the aging process there is often a decreased ability for fine control of systemic inflammation (i.e., the human immune system often displays a progressive and chronic tendency toward a proinflammatory phenotype, also called "inflamm-aging" [31]) (cf. [35]). At the same time, the immune response and excessive inflammation (which is commonly observed in the very recent human coronavirus (COVID-19) pandemic [36-41]) may actually accelerate the progression of brain inflammatory neurodegeneration $[22,42,43]$; furthermore, the hippocampus is reported to be particularly vulnerable to coronavirus infections - which increases the probability of post-infection memory impairment 
and accelerating progression of Alzheimer's disease [43]. Hence, the proposed multitasking combination therapeutic, using (biobased) LCM/ ND nanoemulsion(s), may also display greater effectiveness at different stages of Alzheimer's disease; as a result, this multitasking (drugdelivery) therapeutic could represent a pro- mising way to treat, delay, or even prevent the disease in the future (cf. [44-46]). In addition, very recent (detailed, animal) data indicates such proinflammatory cytokine production and, hence, prolonged inflammation is an underlying cause of "long Covid" (i.e., the inducing of longterm effects from COVID-19 infection) [47].

\section{REFERENCES}

1. Talwar P, Kushwaha S, Gupta R, Agarwal R. Systemic Immune Dyshomeostasis Model and Pathways in Alzheimer's Disease. Front Aging Neurosci. 2019;11:290. DOI: 10.3389/fnagi.2019.00290.

2. Osorio C, Kanukuntla T, Diaz E, et al. The Post-amyloid Era in Alzheimer's Disease: Trust Your Gut Feeling. Front Aging Neurosci. 2019;11:143. DOI: 10.3389/fnagi.2019.00143.

3. Guo JT, Yu J, Grass D, et al. Inflammation-dependent cerebral deposition of serum amyloid a protein in a mouse model of amyloidosis. J Neurosci. 2002;22(14):5900-5909. DOI: 10.1523/JNEUROSCI.22-14-05900.2002.

4. Birch AM, Katsouri L, Sastre M. Modulation of inflammation in transgenic models of Alzheimer's disease. J Neuroinflammation. 2014;11:25. DOI: 10.1186/1742-2094-11-25.

5. D'Arrigo JS. Nanotargeting of Drug(s) for Delaying Dementia: Relevance of Covid-19 Impact on Dementia. Am J Alzheimers Dis Other Demen. 2020;35:1-12. DOI: 10.1177/1533317520976761.

6. D'Arrigo JS. Nanotargeting dementia etiology: aiming drug nanocarriers toward receptors for vascular endothelium, serum amyloid $A$, inflammasomes, and oxidative stress. Nano Prog. 2020;2(3):25-30. DOI: 10.36686/Ariviyal.NP.2020.02.03.011.

7. Baranova IN, Vishnyakova TG, Bocharov AV, et al. Serum amyloid A binding to CLA-1 (CD36 and LIMPII analogous-1) mediates serum amyloid $A$ protein-induced activation of ERK1/2 and p38 mitogen-activated protein kinases. J Biol Chem. 2005;280(9):8031-8040. DOI: 10.1074/jbc.M405009200.

8. Mullan RH, McCormick J, Connolly M, et al. A role for the high-density lipoprotein receptor SR-B1 in synovial inflammation via serum amyloid-A. Am J Pathol. 2010;176(4):1999-2008. DOI: 10.2353/ajpath.2010.090014.

9. Erickson MA, Jude J, Zhao H, et al. Serum amyloid A: an ozone-induced circulating factor with potentially important functions in the lung-brain axis. FASEB J. 2017;31(9):3950-3965. DOI: 10.1096/fj.201600857RRR.

10. Robert J, Stukas S, Button E, et al. Reconstituted high-density lipoproteins acutely reduce soluble brain A $\beta$ levels in symptomatic APP/PS1 mice. Biochim Biophys Acta. 2016;1862(5):1027-1036. DOI: 10.1016/j. bbadis.2015.10.005.

11. D'Arrigo JS. Stable Nanoemulsions: Self-Assembly in Nature and Nanomedicine. Elsevier: Amsterdam, 2011.

12. D'Arrigo JS. Alzheimer's Disease, Brain Injury, and C.N.S. Nanotherapy in Humans: Sonoporation Augmenting Drug Targeting. Medical Sci. 2017;5(4):29. DOI: 10.3390/medsci5040029.

13. D'Arrigo JS. Nanotherapy for Alzheimer's disease and vascular dementia: Targeting senile endothelium. Adv Colloid Interface Sci. 2018;251:44-54. DOI: 10.1016/j.cis.2017.12.002.

14. D'Arrigo JS. Treating Dementia Early: Limiting Cellular Damage in Brain Tissue. OBM Geriatrics. 2019;3(2):19. DOI: 10.21926/obm.geriatr.1902057.

15. D'Arrigo JS. Delaying Dementia: Targeted Brain Delivery Using Lipid Cubic Phases. OBM Neurobiology 2019;3(3):13. DOI: 10.21926/obm.neurobiol.1903040.

16. D'Arrigo JS. Targeting Early Dementia: Using Lipid Cubic Phase Nanocarriers to Cross the Blood'Brain Barrier. Biomimetics (Basel). 2018;3(1):4. DOI: 10.3390/biomimetics3010004.

17. Schuchardt M, Prüfer N, Tu Y, et al. Dysfunctional high-density lipoprotein activates toll-like receptors via serum amyloid $A$ in vascular smooth muscle cells. Sci Rep. 2019;9(1):3421. DOI: 10.1038/s41598-01939846-3. 
18. Dal Magro R, Simonelli S, Cox A, et al. The Extent of Human Apolipoprotein A-I Lipidation Strongly Affects the B-Amyloid Efflux Across the Blood-Brain Barrier in vitro. Front Neurosci. 2019;13:419. DOI: 10.3389/ fnins.2019.00419.

19. D'Arrigo JS. Biomaterial to Improve Drug Delivery in Alzheimer's Disease: Linking Major Pathogenic Pathways. OBM Geriatrics. 2020;4(1):10. DOI: 10.21926/obm.geriatr.2001110.

20. D'Arrigo JS. Biomimetic Nanocarrier Targeting Drug(s) to Upstream-Receptor Mechanisms in Dementia: Focusing on Linking Pathogenic Cascades. Biomimetics (Basel). 2020;5(1):11. DOI: 10.3390/ biomimetics501001121.

21. Sorokin AV, Karathanasis SK, Yang ZH, et al. COVID-19-Associated dyslipidemia: Implications for mechanism of impaired resolution and novel therapeutic approaches. FASEB J. 2020;34(8):9843-9853. DOI: 10.1096/ fj.202001451.

22. Naughton SX, Raval U, Pasinetti GM. Potential Novel Role of COVID-19 in Alzheimer's Disease and Preventative Mitigation Strategies. J Alzheimers Dis. 2020;76(1):21-25. DOI: 10.3233/JAD-200537.

23. Heneka MT, Golenbock D, Latz E, et al. Immediate and long-term consequences of COVID-19 infections for the development of neurological disease. Alzheimers Res Ther. 2020;12(1):69. DOI: 10.1186/s13195-02000640-3.

24. Tangestani Fard M, Stough C. A Review and Hypothesized Model of the Mechanisms That Underpin the Relationship Between Inflammation and Cognition in the Elderly. Front Aging Neurosci. 2019;11:56. DOI: 10.3389/fnagi.2019.00056.

25. Lénárt N, Brough D, Dénes Á. Inflammasomes link vascular disease with neuroinflammation and brain disorders. J Cereb Blood Flow Metab. 2016;36(10):1668-1685. DOI: 10.1177/0271678X16662043.

26. Sierksma A, Lu A, Mancuso R, et al. Novel Alzheimer risk genes determine the microglia response to amyloid- $\beta$ but not to TAU pathology. EMBO Mol Med. 2020;12(3):e10606. DOI: 10.15252/emmm.201910606.

27. Srimanee $A$, Regberg J, Hällbrink $M$, et al. Role of scavenger receptors in peptide-based delivery of plasmid DNA across a blood-brain barrier model. Int J Pharm. 2016;500(1-2):128-135. DOI: 10.1016/j. ijpharm.2016.01.014.

28. Lajoie JM, Shusta EV. Targeting receptor-mediated transport for delivery of biologics across the blood-brain barrier. Annu Rev Pharmacol Toxicol. 2015;55:613-631. DOI: 10.1146/annurev-pharmtox-010814-124852.

29. Almer G, Mangge H, Zimmer A, Prassl R. Lipoprotein-Related and Apolipoprotein-Mediated Delivery Systems for Drug Targeting and Imaging. Curr Med Chem. 2015;22(31):3631-3651. DOI: 10.2174/0929867322666 150716114625.

30. Preston JE, Joan Abbott N, Begley DJ. Transcytosis of macromolecules at the blood-brain barrier. Adv Pharmacol. 2014;71:147-163. DOI: 10.1016/bs.apha.2014.06.001.

31. Rea IM, Gibson DS, McGilligan V, et al. Age and Age-Related Diseases: Role of Inflammation Triggers and Cytokines. Front Immunol. 2018;9:586. DOI: 10.3389/fimmu.2018.00586.

32. Liddelow SA, Guttenplan KA, Clarke LE, et al. Neurotoxic reactive astrocytes are induced by activated microglia. Nature. 2017;541(7638):481-487. DOI: 10.1038/nature21029.

33. Clarke LE, Liddelow SA, Chakraborty C, et al. Normal aging induces A1-like astrocyte reactivity. Proc Natl Acad Sci U S A. 2018;115(8):E1896-E1905. DOI: 10.1073/pnas.1800165115.

34. Wang JL, Xu CJ. Astrocytes autophagy in aging and neurodegenerative disorders. Biomed Pharmacother. 2020;122:109691. DOI: 10.1016/j.biopha.2019.109691.

35. Cortes-Canteli M, ladecola C. Alzheimer's Disease and Vascular Aging: JACC Focus Seminar. J Am Coll Cardiol. 2020;75(8):942-951. DOI: 10.1016/j.jacc.2019.10.062.

36. Gonçalves CA, Sesterheim P. Serum amyloid A protein has been undervalued as a biomarker of COVID-19. Diabetes Metab Res Rev. 2021;37(1):e3376. DOI: 10.1002/dmrr.3376.

37. Petrakis D, Margină D, Tsarouhas K, et al. Obesity - a risk factor for increased COVID-19 prevalence, severity and lethality (Review). Mol Med Rep. 2020;22(1):9-19. DOI: 10.3892/mmr.2020.11127. 
38. Zhang $\mathrm{Q}$, Wei $\mathrm{Y}$, Chen $\mathrm{M}$, et al. Clinical analysis of risk factors for severe COVID-19 patients with type 2 diabetes. J Diabetes Complications. 2020;34(10):107666. DOI: 10.1016/j.jdiacomp.2020.107666.

39. Cheng L, Yang JZ, Bai WH, et al. Prognostic value of serum amyloid A in patients with COVID-19. Infection. 2020;48(5):715-722. DOI: 10.1007/s15010-020-01468-7.

40. Li H, Xiang X, Ren H, et al. Serum Amyloid A is a biomarker of severe Coronavirus Disease and poor prognosis. J Infect. 2020;80(6):646-655. DOI: 10.1016/j.jinf.2020.03.035.

41. Fu J, Huang PP, Zhang $S$, et al. The value of serum amyloid $A$ for predicting the severity and recovery of COVID-19. Exp Ther Med. 2020;20(4):3571-3577. DOI: 10.3892/etm.2020.9114.

42. Brown EE, Kumar S, Rajji TK, et al. Anticipating and Mitigating the Impact of the COVID-19 Pandemic on Alzheimer's Disease and Related Dementias. Am J Geriatr Psychiatry. 2020;28(7):712-721. DOI: 10.1016/j. jagp.2020.04.010.

43. Ritchie $\mathrm{K}$, Chan $\mathrm{D}$, Watermeyer T. The cognitive consequences of the COVID-19 epidemic: collateral damage? Brain Commun. 2020;2(2):fcaa069. DOI: 10.1093/braincomms/fcaa069.

44. Wei C, Wan L, Yan $Q$, et al. HDL-scavenger receptor B type 1 facilitates SARS-CoV-2 entry. Nat Metab. 2020;2(12):1391-1400. DOI: 10.1038/s42255-020-00324-0.

45. Manosso LM, Arent CO, Borba LA, et al. Microbiota-Gut-Brain Communication in the SARS-CoV-2 Infection. Cells. 2021;10(8):1993. DOI: 10.3390/cells10081993.

46. Raith M, Kauffman SJ, Asoudeh M, et al. Elongated PEO-based nanoparticles bind the high-density lipoprotein (HDL) receptor scavenger receptor class B I (SR-BI). J Control Release. 2021;337:448-457. DOI: 10.1016/j. jconrel.2021.07.045.

47. Frere JJ. Serafini RA, Pryce KD. et al. A molecular basis of long COVID-19. Cell. 2021. (in press). DOI: 10.2139/ ssrn.3885245.

Received: 21.08 .2021

Accepted: 29.08 .2021 